The $5^{\text {th }}$ International Conference on Family Business and Entrepreneurship

\title{
MANAGEMENT CHALLENGES AND WORK PASSION OF SCHOOL INSTRUCTIONAL LEADERS IN THE NEW PHILLIPPINE SETTING
}

\author{
Ma. Viczie I. Tubongbanua ${ }^{1}$, Evangeline B. Ybanez ${ }^{2}$ \\ ${ }^{1,2}$ Faculty of Business, Colegio de la Purisima Concepcion, Corresponding author: sgs@purisima.edu.ph
}

\begin{abstract}
The pandemic instigated eighty percent of world's children and youth to be out of school posing management challenges among school leaders. This study sought to determine the extent of management challenges and the level of work passion of school instructional leaders (SILs) in the province of Capiz under the new framework and plan of action during the school year 2020-2021. The descriptive survey correlational research design and stratified sampling were used. A researcher-made questionnaire was used to gather data from 222 SILs in the province of Capiz as respondents. The statistical tools used to analyze and interpret data were frequency count, percentage, mean, t-test, Analysis of Variance and Pearson $r$. The level of significance was set at 0.05 alpha. The results revealed that SILs were challenged in terms of management and were remarkably passionate in their work. The extent of management challenges and the level of work passion of school instructional leaders varied in educational qualification and length of service. Demographic profile as to sex, age, and school category did not affect the extent of management challenges and the level of work passion of SILs. Furthermore, the extent of management challenges was significantly related to the level of work passion of the SILs.
\end{abstract}

Keywords: Management, Challenges, Instructional leaders, Work passion

\section{Introduction}

Unknown to the world, reports reached the World Health Organization (WHO) several viral pneumonia cases with no known cause were spreading in Wuhan, China. Together with the festive countdowns and merry celebrations, the virus lurked around causing panic and fears followed by social, economic and academic freeze. The Secretary of Education firmly advocated "education must continue," no matter what challenges or dangers may be present (Briones, 2020). Innovations were made to meet health protocols set by the government, several learning modality were devised to suit the no face-to-face set up, and teachers underwent numerous and rigid online training and webinars to capacitate themselves.

Some school instructional leaders' work fell within the bounds of their former roles; supervising teaching, analyzing curriculum and establishing parents and community connectedness. The Philippine's Department of Education (DepEd) cancelled all school-related activities and programs led to the nationwide suspension of classes and abrupt closing of School Year 2019-2020. The pandemic inputted inequities and gaps in the educational system and their impacts in stark relief, placing new pressures on school leaders and educators to engage in triage from afar (Stone-Johnson and Weiner, 2020). The responsibilities of school instructional leaders expanded coupled with management challenges they had never experienced. The Covid-19 health crisis caused more than 1.6 billion children and youth to be out of school in 161 countries, accounting for $80 \%$ of the world's enrolled students (Saavedra, 2020) and UNESCO (2020) reported more than 90\% of young people around the world no longer attended physical school. Across the globe, positive cases hit an unacceptable scale with rapid increase of cases and spread of the virus worldwide. 
However, handing out food to families in the community, working with telecommunications companies to provide Internet connection to students, distributing learning modules and activities sheets, and serving as technical support constituted the delivery shift of education to distance learning. Coping with challenges included new working set-up, responding to new learning modality, communicating with teachers and superiors amidst unreliable connectivity, and considering health and wellness issues in decision-making. Significantly, both the Provincial and City Schools Division Office rose up to squarely face the resulting chaos and changes that the pandemic posed for the educational sector. In the forefront were the schoolse instructional leaders. They need to ascertain the extent of management challenges and cultivate high level work passion school instructional leaders responding to the new framework and formulate a plan of action that would best serve the educational sector of the Province of Capiz. These concepts led the research to be pursued to determine the challenges that school heads faced as they managed their respective schools, assess their passion for work, and subsequently to produce a tangible output that will be accessible and useful to school instructional leaders and the department.

\section{Statement of the Problem}

This study investigated the extent of management challenges and the level of work passion of school instructional leaders in the province of Capiz under the new framework and plan of action. Specifically, this study aimed to answer the following questions:

1. What is the extent of management challenges of school instructional leaders in the province of Capiz as a whole and in terms of instructional leadership, learning environment, human resource management and development, and school leadership, management, and operations?

2. What is the level of work passion as a whole and in terms of cognitive, behavioral, and affective?

3. Is there a significant difference on the extent of management challenges when grouped according to sex, age, school category, educational qualification, and length of service?

4. Is there a significant difference on the level of work passion when grouped according to sex, age, school category, educational qualification, and length of service?

5. Is there a significant relationship between the extent of management challenges and the level of work passion under the new framework and plan of action?

6. What possible proposed plan of action can be drawn from the results of the study?

\section{Hypotheses}

Based on the statement of the problem, the following hypotheses were forwarded:

1. There is no significant difference on the extent of management challenges when grouped according to sex, age, school category, educational qualification, and length of service.

2. There is no significant difference on the level of work passion when grouped according to sex, age, school category, educational qualification, and length of service.

3. There is no significant relationship between the extent of management challenges and the level of work passion under the new framework and plan of action.

\section{Theoretical Framework}

The study was based on two theories, namely the systems theory and the self-efficacy theory. The systems theory viewed organization as a social system consisting of individuals who cooperate within a formal framework, drawing resources, people, finance from their environment and putting back into that environment the products they produce or the services they offer.

Self-efficacy is the belief, or confidence, that one can successfully execute a behavior required to produce an outcome such that the higher the level of self-efficacy, the more an individual believes he or she can execute the behavior necessary to obtain a particular outcome (Bandura, 1977). A central idea posed in social cognitive theory is that success experiences raise self-efficacy but repeated failures lower self-efficacy. Acquiring the ability to minimize negative thoughts and keep a positive outlook when facing difficult or challenging tasks help individuals achieve a level of self-efficacy and lower their negative emotional arousal as well as social relationships (Bandura, 1994; 1997; Luszynska \& Scwarzer, 2008; Schwarzar \& Luszcynska, 2007.

Strong self-efficacy beliefs enhance human accomplishment and personal well-being in many ways. The beliefs that people with high self-efficacy hold influence on what they feel and think about others, thus motivating them to action. Individuals with enhanced self-efficacy are those whose thoughts and feelings lead to motivated action. High self-efficacy helps create feelings of serenity in approaching difficult tasks and activities. At each of these levels, educational decisions are influenced by different actors, for example, at the school level the school committee, the head teacher, teachers, and parents make certain decisions and give opinions on the management of the school. The theory was used since it embodies the three components of work passion, to wit: cognitive, 
affective, and behavioral.

Bandura (1994) described self-efficacy as a person"s judgment of his or her ability to achieve or accomplish an action and supports the importance of a determinant for behavioral performance. People with a strong sense of personal competence in a domain approach difficult task in that domain as challenges to be mastered rather than as dangers to be avoided; have great intrinsic interest in activities, set challenging goals and maintain a strong commitment to them, heighten their efforts in the face of failure, more easily recover their confidence after failures or setbacks and attribute failure to insufficient effort or deficient knowledge and skills which they believe they are capable of acquiring. The systems theory emphasizes unity and integrity of the organization and focuses on the interaction between its component parts and the interactions with the environment. Moreover, enhanced self-efficacy, secondary to repeated successes often generalizes to new situations (Bandura, 1977).

\section{Conceptual Framework}

The significant relationship between the extent of management challenges and the level of work passion of school instructional leaders in the Schools division offices of Roxas City and of Capiz under the new framework and plan of action was determined. It is presumed that the extent of management challenges and the level of work passion of the school instructional leaders have a significant relationship. The variables were utilized to ascertain the extent of management challenges and establish the level of work passion of school instructional leaders in the City of Roxas and the province of Capiz under the new framework and plan of action. The relationship between the socio-demographic profile as an independent variable and the extent of management challenges and level of work passion as dependent variables is presented. For a visual presentation, a schematic diagram is shown in Figure 1 below.

INDEPENDENT VARIABLE

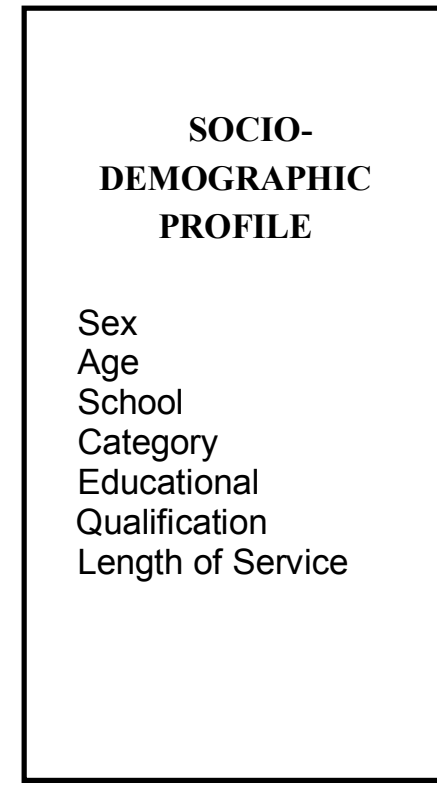

DEPENDENT VARIABLES

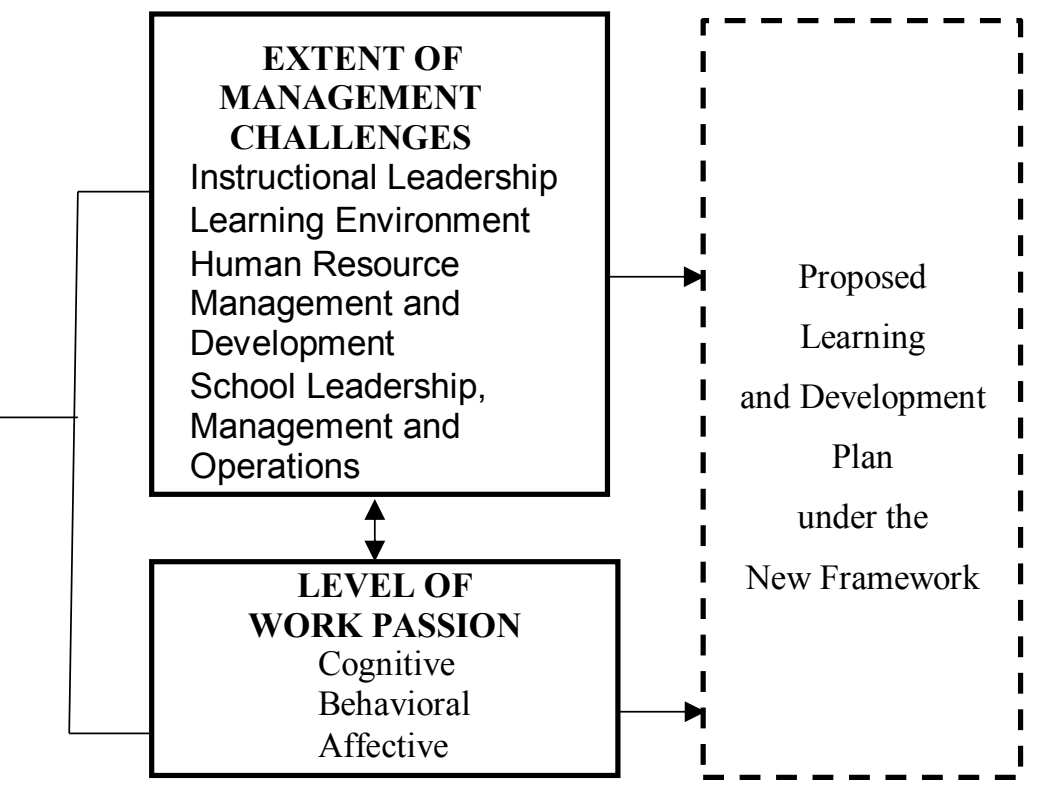

Figure 1. The schematic diagram showing the relationship of the variables that were considered in the study.

\section{Literature Review}

Management challenges. Follet, tagged as the Mother of Modern Management, simply defined management "as the art of getting things done through people." According to Van Fleet and Peterson, management is "a set of activities directed at the efficient and effective utilization of resources in the pursuit of one or more goals." Brech articulated four elements of management as being planning, control, coordination, and motivation. In relation to schools, it would not suffice to merely say that management indicates handling its affairs. School management entails running the school along the desired school policies, considering all aspects of its materials, human resources, programs, equipment, and integrating them into a fruitful whole. Education institutions require its management to plan, organize, direct, control and evaluate day to day activities to accomplish education goals through coordination of education personnel and allocated budgets 
(Farah, 2013).

Like any entity, schools and other centers of formal learning necessitate concrete and purposive actions to be able to achieve its set goals by the effective and efficient handling of its human and material resources. Managers meet these responsibilities by closely monitoring the results of the plan, identifying deviations from the plan, and organizing solutions to these problems. Schools are not exempted from being managed and this is where the role of SILs as managers inevitably come in. The reality of the situation is that sometimes, managers need to lead and at times, leaders have to manage (Northouse, 2011). Cho and Ringquist (2011) noted in their study that although all managers are not leaders, some managers play leadership roles. They also noted that not all managers are leaders and vice versa. They are supposed to be the role models when it comes to passion for work and practice self-management since the reduction in the number of staff reporting for office is noticeable in this pandemic time.

These different sections have different expectations and wishes from the school administration: parents in the selection of teachers, political groups on the registration of students who are most outside the registration area, public union in terms of membership, and religious groups in making demonstrations in school, hanging posters, registering students in their dormitories with the school and participating in the meetings (Urun and Gökçe, 2015).The strong association between measures of school safety and average student achievement suggests that students are unable to concentrate on academics when they fear for their physical well-being (Steinberg, Allens worth, \& Johnson, 2011). As school is a public place where crowds are unavoidable and children are vulnerable, there is a need to strengthen policy in terms of the delivery of instruction - to provide opportunities for online learning platforms. With this transition to the new normal, from the four corners of the classroom to the borders of virtual reality, every learning institution needed to study how successful online learning is in providing quality education and outcomes-based education to students (Basilaia \& Kvavadze, 2020). Thus, students, faculty members and non-teaching staff should be required to wear face masks and maintain physical distance with each other when going to school. A similar study conducted in Namibia (Mushaandja, 2013) resulted in the following: chronic stress, overloaded schedule, simultaneous assimilation both to a new school environment and to a leadership position, adjustment from teachers being peers to being subordinates, and the sense of isolation from supervisors. With schools to reopen doors the following school year, it is vital to plan how they will be able to pursue their mission of implementing quality education to every student.

addition, laboratory activities in sciences and other subjects that require performance such as Physical Education and culture and arts would be limited to paper and pen test, unless schools require students to be physically present for performance assessment. One of the challenges of schools is to reduce studentteacher-ratio which will lead to problems like lack of classrooms and other physical plants and facilities, inadequacy of teachers and shortage of learning materials. According to UNESCO, 1.6 billion young people have been out of school during this crisis and as Zhao (2020) points out virtually all schools have been paused"e and teaching has been significantly re-organized. However, if the SILs were to provide personalized professional learning for their staff, the SILs' turn would increase the relevance of professional development and at the same time strengthen their own relationships with staff members.

\section{Research Method}

The study used descriptive correlational since it described (1) the extent of management challenges of SILs as a whole and in terms of instructional leadership, learning environment, human resource management and development, and school leadership, management, and operations, and (2) the level of work passion as a whole and in terms of cognitive, behavioral, and affective (3) the significant difference in the extent of management challenges among SILs as a whole and when they were grouped according to sex, age, school category, educational qualification, and length of service; and (4) the significant relationship between the extent of management challenges among SILs and the level of their work passion under the new framework and plan of action. Likewise, it was limited to measuring their level of work passion, encompassing its cognitive, behavioral, and affective components.

The respondents of this study were limited to a random sample (using Slovin"s formula sampling technique) of 222 from a population of 521 public school heads in the province of Capiz, from the Schools Divisions of Roxas City and Capiz for school year 2020-2021. A researcher-made questionnaire was used to gather needed data. It contained the mean scale (4.21-5.00 - very high; 3.41-4.20 - high; 2.61-3.40-fairly high; 1.81-2.60 - low; 1.00-1.80 -very low) and description that facilitated interpretation. Data gathered were analyzed using frequency count, percentage, mean, t-test, ANOVA, and Pearson-r. Frequency count and percentage were used for descriptive statistics and the t-test and ANOVA for testing the significant differences. Pearson-r was used to determine the significant relationship between the extent of management 
challenges and the level of work passion. The level of significance was set at alpha .05. All statistical data were computer processed.

Due to the pandemic, the DepEd mandated the work-from-home set up for all its employees. This working arrangement limited the researcher from easily floating the research questionnaires. The researcher then opted the use of Google form but not all respondents had reliable internet connection nor were computer savvy. The items on the research instrument may not have addressed or catered the full range of management challenges and work passion of the school instructional leaders. Some response options would have required participants to assign relative values to items.

\section{Results and Discussion}

\section{Extent of management challenges of school instructional leaders}

Data on the extent of management challenges of the SILs in the province of Capiz reveal that they encountered multiple challenges under the new normal set-up. The overall mean of 4.556 indicated the management challenges encountered were "Very High." Results also revealed each component obtained a "Very High" rating. It can be inferred SILs in the province of Capiz perceive that the component encompassing school leadership style, resources, linkages, and operations as the most challenging work with highest mean of 4.590 among all the components. Meanwhile, Human Resource Management and Development attained was low though with a Very High" rating. It showed professional development of teachers posed lesser challenges than the other three under the new framework and plan of action.

Table 1. Extent of management challenges of SILs in the province of Capiz.

\begin{tabular}{lcc}
\hline \multicolumn{1}{c}{ Components } & Grand Mean & $\begin{array}{c}\text { Verbal } \\
\text { Interpretation }\end{array}$ \\
\hline Instructional leadership & 4.572 & Very High \\
Learning environment & 4.576 & Very High \\
Human resource management and development & 4.486 & Very High \\
School leadership, management, and operations & 4.590 & Very High \\
Overall Mean & 4.556 & Very High \\
\hline
\end{tabular}

Instructional leadership. The data on the extent of management challenges as to instructional leadership has a grand mean of 4.572 was "Very High" which means that managing and directing the school amidst the pandemic with focus on curriculum and instruction presented a very challenging role to the respondents. Table 2 showed that monitoring proper distribution and collection of learning resources is considered as the biggest challenge by the SILs. The school in the distribution and retrieval of modules as scheduled due to the sudden shift towards distance learning; establishment of proper procedures and mechanisms in the orientation of their teachers, learners and parents or guardians regarding policies and guidelines of learning delivery modalities. The results indicated, SILs face greater complexity in fulfilling their while pressure is relentless and the options are limited. As Netolicky (2020), stated "In a time of crisis, school leaders are walking a tightrope without a safety net. There are no precedents and no guides to leading schools in a pandemic." Leithwood, Harris, and Hopkins (2020) asserted instructional leadership practices have changed considerably and maybe, irreversibly because of the COVID-19 pandemic.

Learning environment. The extent of management challenges of SILs in terms of learning environment has a grand mean of 4.576 was interpreted as "Very High." It implied SILs see that this component presented a huge challenge to them because schools operate in an entirely new and altered scenario; "made sure that health protocols are properly observed and followed during the distribution and collection of learning materials; required the teachers to disseminate information to the learners regarding precautionary and mitigating measures concerning Covid-19; "supervised the implementation of the prescribed health protocols inside the school premises at all times; ensured the presence of school clubs and other organizations and supervised their activities during this time of pandemic; and "ensured that the extensive program on the enhancement of skills and talents of the different members of the school community still exists." 
Table 2. Extent of management challenges of SILs in terms of instructional leadership

\begin{tabular}{llcc}
\hline \multicolumn{1}{c}{ Statements } & Mean & $\begin{array}{c}\text { Verbal } \\
\text { Interpretation }\end{array}$ \\
\hline 1. & $\begin{array}{l}\text { Oriented the teachers, parents and learners about Learning Delivery Modality } \\
\text { policies and guidelines to ensure that everyone is well informed and guided. }\end{array}$ & 4.644 & Very High \\
2. & $\begin{array}{l}\text { Encouraged the teachers to develop and produce supplementary learning resources } \\
\text { and materials suited to the learners' competencies. }\end{array}$ & 4.608 & Very High \\
3. $\begin{array}{l}\text { Established the inventory system of the quality-assured modules, supplementary } \\
\text { learning resources and materials. }\end{array}$ & 4.441 & High \\
4. $\begin{array}{l}\text { Assured that the locally developed supplementary learning resources and materials } \\
\text { are of quality. }\end{array}$ & 4.418 & High \\
5. $\begin{array}{l}\text { Developed an efficient system of distribution and collection of the learning } \\
\text { resources. }\end{array}$ & 4.693 & Very High \\
6. $\begin{array}{l}\text { Monitored proper distribution and collection of learning resources. } \\
\text { 7. Monitored and reported progress on the conduct of distance learning. }\end{array}$ & 4.743 & $\begin{array}{l}\text { Very High } \\
\text { 8. Ensured that the school has an educational platform or Learning Management }\end{array}$ \\
$\begin{array}{l}\text { System (LMS) available. } \\
\text { Developed strategies to get feedback from parents about the learning modality that } \\
\text { the school adopted. }\end{array}$ & 4.504 & Very High \\
10. Monitored the learners' records by checking the Weekly Home Learning Plan of \\
the teachers.
\end{tabular}

Results showed SILS cannot directly ensure that the school personnel and other members of the community are observing prescribed health protocols due to some external factors and unavoidable circumstances may happen that are beyond their control, like different and less stringent health guidelines and practices, possible gathering of crowds, and unpredictable weather conditions.

Table 3. Extent of management challenges of SILs in terms of learning environment

\begin{tabular}{|c|c|c|}
\hline Statements & Mean & $\begin{array}{c}\text { Verbal } \\
\text { Interpretation }\end{array}$ \\
\hline $\begin{array}{l}\text { 1. Ensured that the school has enough resources, commodities and } \\
\text { infrastructure to assure the safety of teaching personnel and support } \\
\text { staff. }\end{array}$ & 4.464 & Very High \\
\hline $\begin{array}{l}\text { 2. Required the teachers to disseminate information to the learners } \\
\text { regarding precautionary and mitigating measures concerning Covid-19. }\end{array}$ & 4.756 & Very High \\
\hline $\begin{array}{l}\text { 3. Reminded the school stakeholders by posting information ads on the } \\
\text { most conspicuous places within or nearby the school premises. }\end{array}$ & 4.653 & Very High \\
\hline $\begin{array}{l}\text { 4. Ensured the presence of school clubs and other organizations and } \\
\text { supervised their activities during this time of pandemic. }\end{array}$ & 4.171 & High \\
\hline $\begin{array}{l}\text { 5. Make sure that health protocols are properly observed and followed } \\
\text { during the distribution and collection of learning materials. }\end{array}$ & 4.806 & Very High \\
\hline $\begin{array}{l}\text { 6. Ensured that the extensive program focusing on the enhancement of } \\
\text { physical, mental, and emotional well-being of the whole school } \\
\text { community is properly implemented. }\end{array}$ & 4.576 & Very High \\
\hline $\begin{array}{l}\text { 7. Ensured that the extensive program on the enhancement of skills and } \\
\text { talents of the different members of the school community still exists. }\end{array}$ & 4.351 & High \\
\hline $\begin{array}{l}\text { 8. Make sure that the school facilities are cleaned, sanitized, and } \\
\text { disinfected on a regular basis. }\end{array}$ & 4.662 & Very High \\
\hline 9. Make sure that the school surroundings are well-maintained. & 4.617 & Very High \\
\hline $\begin{array}{l}\text { 10. Supervised the implementation of the prescribed health protocols inside } \\
\text { the school premises at all times. }\end{array}$ & 4.702 & Very High \\
\hline Grand Mean & 4.576 & Very High \\
\hline
\end{tabular}

Human resource management and development. The extent of management challenges of SILs in terms of human resource management and development has a grand mean of 4.486 interpreted as "Very High." Results forwarded Human Resource Management and Development challenges consisted ensure that 
teachers are well-oriented on the new DepEd policies and guidelines pertaining to the Basic Education Learning Continuity Plan (BE-LCP)" conducted regular meetings with teachers to confer about school accomplishment and development needs and objectives provided school-based In-Service Training (INSET) for teachers and other school personnel and allowed them to explore their ideas in solving management problems, allowed the teachers to conduct community-based research particularly on the challenges brought about by the changes in the educational system," and "extended the programs for technology to students and parents to make them embrace its importance in today"s education. As Cabaro, et. al., (2014) suggested SILs and teachers must adapt their work methodology, by carrying out a training process that serves as a guide to assimilate the context caused by the coronavirus crisis.

Table 4. Extent of management challenges of SILs in terms of human resource management and development

\begin{tabular}{|c|c|c|c|}
\hline & Statements & Mean & $\begin{array}{c}\text { Verbal } \\
\text { Interpretation }\end{array}$ \\
\hline 1. & $\begin{array}{l}\text { Provided professional development for teachers in implementing } \\
\text { the learning modality of the school, based on the emerging and felt } \\
\text { needs to improve the academic performance of the learners }\end{array}$ & 4.576 & Very High \\
\hline 2. & $\begin{array}{l}\text { Conducted technology enhancement programs for teachers } \\
\text { through webinars/seminars, trainings, and workshops }\end{array}$ & 4.491 & Very High \\
\hline 3. & $\begin{array}{l}\text { Extended the programs for technology to students and parents to } \\
\text { make them embrace its importance in today's education }\end{array}$ & 4.225 & High \\
\hline 4. & $\begin{array}{l}\text { Ensured that teachers are well-oriented on the new DepEd policies } \\
\text { and guidelines pertaining to the Basic Education Learning } \\
\text { Continuity Plan }\end{array}$ & 4.671 & Very High \\
\hline 5. & $\begin{array}{l}\text { Made sure that teachers can freely access the needed resources } \\
\text { accorded by the Department such as DepEd Commons and } \\
\text { Learning Resource Management and Development System }\end{array}$ & 4.612 & Very High \\
\hline 6. & $\begin{array}{l}\text { Conducted regular meetings with teachers to confer about school } \\
\text { accomplishment and development needs and objectives }\end{array}$ & 4.653 & Very High \\
\hline 7. & $\begin{array}{l}\text { Institutionalized the provision of technical assistance to teachers } \\
\text { for them to cope with the demands of distance learning }\end{array}$ & 4.558 & Very High \\
\hline 8. & $\begin{array}{l}\text { Ensured the compliance to the Results-based Performance } \\
\text { Management System and other professional development } \\
\text { activities for teachers that are deemed necessary for teachers }\end{array}$ & 4.536 & Very High \\
\hline & $\begin{array}{l}\text { Provided school-based INSET for teachers and other school } \\
\text { personnel and allowed them to explore their ideas in solving } \\
\text { management problems }\end{array}$ & 4.252 & High \\
\hline & Allowed the teachers to conduct community-based research & 4.279 & High \\
\hline & Grand Mean & 4.486 & Very High \\
\hline
\end{tabular}

School leadership, management and operations. Data on school leadership, management and operations challenges had 4.590 mean interpreted "Very High." When appreciated together with the other three components of management challenges, it indicated as highly substantial and most challenging. Results implied SILs are heavily challenged on leadership style they exercise, school resources that schools own and use, linkages, and operations they face in this pandemic. They made updated liquidation reports, while the conduct of fund raising projects are in compliance with existing laws and policies. They managed the school funds according to priority needs and conducted fund-raising projects as the least of their concerns were less feasible. However, Revsee Escobedo (2019) stated insufficient budget and supplies of bond paper contributed to the delay in the printing of learning materials. While schools have a budget allocation for the shift to distance learning, budget can be easily depleted due to the sheer number of modules that need to be printed and distributed to the learners plus incidental expenses such as materials, supplies, transportation cost, etc. which poses a huge concern to SILs in their management of school finances. 
Table 5. Extent of management challenges of SILs in terms of school leadership, management and operations

\begin{tabular}{llc}
\hline \multicolumn{1}{c}{ Statements } & Mean & $\begin{array}{c}\text { Verbal } \\
\text { Interpretation }\end{array}$ \\
\hline 1. $\begin{array}{l}\text { Managed the school funds according to priority needs and } \\
\text { accounted for such funds in updated liquidation reports. }\end{array}$ & 4.801 & Very High \\
2. $\begin{array}{l}\text { Established linkages or partnerships with school } \\
\text { stakeholders for the donation of school supplies, } \\
\text { equipment, and health commodities. }\end{array}$ & 4.644 & Very High \\
3. Ensured the 100\% resolution of conflicts within the \\
$\begin{array}{l}\text { school premises, if there is any. } \\
\text { Ensured that the school has a help desk personnel whose } \\
\text { main task is to answer questions and other queries raised } \\
\text { by any member of the school community. }\end{array}$
\end{tabular}

Level of work passion of school instructional leaders

Data on the level of work passion showed desire and belief to sustain deep work commitment. The overall mean of 4.732 indicated "Very High" work passion which comprised affective, cognitive and behavioral the mean of 4.826 for affective indicated that SILs are compassionate and open in creating a fair atmosphere and harmony in the school. It concurred Buenviaje (2016), work passion does not only make SILs maintain a high level of work intensity, but it also renders their work meaningful in their eyes. Drysdale et al., (2011) resonated vision, personal philosophy based on meaningful values, and courage; characteristics of school principals are the sources for them to explore the outer limits of their roles towards what they term 'augmented' and 'potential' roles. Likewise, passion is a strong inclination towards loved, valued and self-defining cause' where considerable time and energy are invested (Rip, Vallerand \& Lafrenière 2012: 1) which serves as fuel that allows people to engage in a deliberate, repeated, and relentless practice so that skills in the activity are improved (Bonneville-Roussy, Lavigne \& Vallerand, 2011).

Table 6. Level of work passion of SILs in the province of Capiz

\begin{tabular}{lccc}
\hline & Components & Grand Mean & Verbal Interpretation \\
\hline Cognitive & 4.637 & Very High \\
Behavioral & 4.734 & Very High \\
Affective & 4.826 & Very High \\
Overall Mean & 4.732 & Very High \\
\hline
\end{tabular}

Cognitive. Data on the level of work passion in terms of cognitive ability has a grand mean of 4.637 interpreted as "Very High". SILs are greatly seeing one's identity in terms of one's work. They significantly see their work as an identity meaningful for them and that their work is their identity; support and encourage positive and cooperative relationships with the members of the school community; give verbal, written or monetary recognition for somebody with exemplary performance; assist the future career planning of the members in the school; and give opportunities to chart one's future career path in the school organization. Results implied SILs are greatly passionate about creating collaborations but less passionate about the giving of recognition, personal and professional growth, and connectedness with community members and colleagues. 
Table 7. Level of work passion of SILs in terms of cognitive

\begin{tabular}{|c|c|c|}
\hline Statements & Mean & Verbal Interpretation \\
\hline $\begin{array}{l}\text { 1. Understand how one's work during these trying times adds } \\
\text { value to the school organization and create positive results. }\end{array}$ & 4.639 & Very High \\
\hline $\begin{array}{l}\text { 2. Believe that the school culture encourages commitment and } \\
\text { dedication. }\end{array}$ & 4.693 & Very High \\
\hline $\begin{array}{l}\text { 3. Support and encourage positive and cooperative } \\
\text { relationships with the members of the school community. }\end{array}$ & 4.747 & Very High \\
\hline $\begin{array}{l}\text { 4. Have the ability, skill and knowledge on how given tasks are } \\
\text { performed. }\end{array}$ & 4.617 & Very High \\
\hline $\begin{array}{l}\text { 5. Give information and authority to empower others in making } \\
\text { decisions concerning the school. }\end{array}$ & 4.621 & Very High \\
\hline $\begin{array}{l}\text { 6. Make a conscious effort to build rapport with the members } \\
\text { of the school community. }\end{array}$ & 4.680 & Very High \\
\hline $\begin{array}{l}\text { 7. Know the boundaries and limits in regard to decision-making } \\
\text { authority. }\end{array}$ & 4.702 & Very High \\
\hline $\begin{array}{l}\text { 8. Give verbal, written or monetary recognition for somebody } \\
\text { with exemplary performance. }\end{array}$ & 4.554 & Very High \\
\hline $\begin{array}{l}\text { 9. Assist the future career planning of the members in the } \\
\text { school. }\end{array}$ & 4.554 & Very High \\
\hline \multirow[t]{2}{*}{$\begin{array}{l}\text { 10. Give opportunities to chart one's future career path in the } \\
\text { school organization. }\end{array}$} & 4.554 & Very High \\
\hline & 4.637 & Very High \\
\hline
\end{tabular}

As Mao and Hsieh (2012) stated, positive relations or having and maintaining friendships at work among peers, employees and other members of the community are essential are relations through different kinds but all are equally important and that each matters. Similarly, Fisher (2010) posited "high quality relationships" with other people are a fundamental source of happiness and well-being at work, and a source of energy for organizational members.

Behavioral Data on behavior as one of the components of the level of work passion of the respondents reveal a grand mean of 4.734 with description "Very High." It is indicative of massive willingness to learn and the great desire to improve, and to continuously give their best in performing their tasks and duties.

Results pointed SILs are fair and decide what is beneficial to all; perform given tasks to the best of my ability" and "always adhere to the Department of Education's policies, rules, and regulations. Results reflected SILs highly committed themselves to the process of learning new skills and acquiring additional knowledge on an on-going basis. Findings coincide of Delloite (2013) passionate individuals are curious, and have high orientation to learn and refresh their skills, because they are highly interested in what they do. As Self-Determination theory implied work passion is one of the internal motivations that encourage an individual to give his or her best in the workplace.

Affective. The level of work passion of the respondents in terms of affective was described "Very High." It consisted briefly proud of my profession; have the intention to stay in my profession and possess a solid relationship with my colleagues that is built on trust and integrity. Results suggested being passionate about one's profession and experiencing positive emotions while exercising such profession which helps build a positive attitude towards an individual's work because they feel enthusiasm, energy, and aliveness while at work.

This indicated school heads have higher discernment of staying and growing with the profession along with their colleagues. Dubreuil, Forest, and Courcy (2014) cited employees with stronger harmonious passion towards their work would have a higher level of performance because passion would help lead their vitality and concentration to higher intensities. 
Table 8. Level of work passion of SILs in terms of behavioral

\begin{tabular}{|c|c|c|}
\hline Statements & Mean & Verbal Interpretation \\
\hline $\begin{array}{l}\text { 1. Consider work to be worthwhile and should be proud of } \\
\text { individual actions and contributions to the Department of } \\
\text { Education. }\end{array}$ & 4.743 & Very High \\
\hline $\begin{array}{l}\text { 2. Perceive an environment and culture that enhance collaboration, } \\
\text { cooperation and encouragement among the members. }\end{array}$ & 4.734 & Very High \\
\hline $\begin{array}{l}\text { 3. Perceive an environment where people have the opportunities to } \\
\text { learn, grow professionally, and develop skills that lead to } \\
\text { advancement and career growth. }\end{array}$ & 4.756 & Very High \\
\hline $\begin{array}{l}\text { 4. Consider an environment where the leader is trusted and efforts } \\
\text { have been exerted to form interpersonal connection with every } \\
\text { member. }\end{array}$ & 4.698 & Very High \\
\hline $\begin{array}{l}\text { 5. Expect that each member extends extra effort for the success of } \\
\text { the school organization. }\end{array}$ & 4.644 & Very High \\
\hline $\begin{array}{l}\text { 6. Influence the members to go beyond the call of their duty and } \\
\text { work efficiently and effectively at all times. }\end{array}$ & 4.666 & Very High \\
\hline 7. Perform given tasks to the best of my ability. & 4.783 & Very High \\
\hline 8. Be fair and decide what is beneficial to all. & 4.806 & Very High \\
\hline $\begin{array}{l}\text { 9. Always exhibit confidence to all members of the school } \\
\text { community. }\end{array}$ & 4.720 & Very High \\
\hline $\begin{array}{l}\text { 10. Always adhere to the Department of Education's policies, rules, } \\
\text { and regulations. }\end{array}$ & 4.783 & Very High \\
\hline Grand Mean & 4.734 & Very High \\
\hline
\end{tabular}

Table 9. Level of work passion of SILs in terms of affective

\begin{tabular}{|c|c|c|}
\hline Statements & Mean & $\begin{array}{c}\text { Verbal } \\
\text { Interpretation }\end{array}$ \\
\hline 1. Be passionate about my work. & 4.828 & Very High \\
\hline 2. Have the intention to stay in my profession. & 4.788 & Very High \\
\hline 3. Be proud of my profession. & 4.851 & Very High \\
\hline 4. Be willing to collaborate with others. & 4.837 & Very High \\
\hline $\begin{array}{l}\text { 5. Be encouraged to promote and create positive relationships with } \\
\text { others. }\end{array}$ & 4.833 & Very High \\
\hline $\begin{array}{l}\text { 6. Treat others with respect and in accordance with the Professional } \\
\text { Code of Ethics. }\end{array}$ & 4.846 & Very High \\
\hline $\begin{array}{l}\text { 7. Recognize the concept of fairness among the members of the } \\
\text { school organization. }\end{array}$ & 4.842 & Very High \\
\hline $\begin{array}{l}\text { 8. Consider compassion and openness as essential elements for } \\
\text { creating harmonious relationships within the school community. }\end{array}$ & 4.842 & Very High \\
\hline $\begin{array}{l}\text { 9. Possess a solid relationship with my colleagues that is built on trust } \\
\text { and integrity. }\end{array}$ & 4.788 & Very High \\
\hline $\begin{array}{l}\text { 10. Take interest in employees' welfare and wellness in order to } \\
\text { establish and maintain a good relationship with them. }\end{array}$ & 4.801 & Very High \\
\hline Grand Mean & 4.826 & Very High \\
\hline
\end{tabular}

Difference on management challenges of school instructional leaders according to selected profiles The socio-demographic profile of the respondents includes their sex, age, school category, educational qualification, and length of service. Findings showed there were 165 female SILs, comprising 74.32\%; middle aged, administrators/SILs of elementary schools, master's degree holders, $124(55.86 \%)$ were in elementary schools, $64(28.83 \%)$ are handling secondary schools, and $34(15.31 \%)$ are in integrated schools. This finding implied that most of the respondents are handling elementary schools.

Educational qualification. Majority of the respondents are master's degree holders, comprising 104 or $46.85 \%$. It appears that 61 or $27.48 \%$ have a bachelor's degree working for more than ten years and 57 or $25.67 \%$ are doctorate degree graduates. 
Length of service. Out of the 222 respondents, six or $2.70 \%$ are in three years and below of service, 48 or $21.62 \%$ are in four to ten years of service, and $168(75.68 \%)$ had worked for more than ten years at SIL.

Table 10. Demographic profile of the respondents

\begin{tabular}{lcc}
\hline \multicolumn{1}{c}{ Respondents } & Frequency & Percentage \\
\hline Sex & 57 & 25.68 \\
Male & 165 & 74.32 \\
Female & & \\
\hline Age & 48 & 21.62 \\
$56-65$ years old & 111 & 50.00 \\
$46-55$ years old & 63 & 28.38 \\
36-45 years old & & \\
\hline School category & 124 & 55.86 \\
Elementary Schools & 64 & 28.83 \\
Secondary Schools & 34 & 15.31 \\
Integrated Schools & & \\
\hline Educational qualification & 61 & 27.48 \\
Bachelor's Degree & 104 & 46.85 \\
Master's Degree & 57 & 25.67 \\
Doctor's Degree & & \\
\hline Length of service & 6 & 2.70 \\
3 years and below & 48 & 21.62 \\
4-10 years & 168 & 75.68 \\
More than 10 years & & \\
\hline
\end{tabular}

Table 11 shows educational qualification and length of service have significant difference while age, sex and school category revealed significant different. Educational qualification and length of service posed significant relationships to management challenges of SILs. The null hypothesis was rejected. However for sex, age and second category the null hypothesis was accepted which indicated insignificant relationship to management challenges of SILs. Summarily, majority of the socio-demographic profile components namely: sex, age, and school category do not show any significance. On the other hand, only the components of educational qualification and length of service presented significance.

Table 11. Difference on extent of management challenges of SILs according to selected profiles

\begin{tabular}{lccl}
\hline \multicolumn{1}{c}{ Component } & t or F-value & $\begin{array}{c}\text { Significant } \\
\text { Value }\end{array}$ & Probability \\
\hline 1. Sex & 0.128 & 0.899 & Not Significant \\
2. Age & 0.131 & 0.877 & Not Significant \\
3. School category & 0.059 & 0.943 & Not Significant \\
4. Educational qualification & 4.553 & 0.012 & Significant \\
5. Length of service & 4.058 & 0.019 & Significant \\
\hline
\end{tabular}

Difference in level of work passion of school instructional leaders according to selected profiles

Data in Table 12 describe the significant differences between certain components of the socio-demographic profile of the SILs and their level of work passion. Findings showed no significant difference existing on the level of work passion of SILs when the components of sex, age and school category are considered. The hypothesis for educational qualification and length of service were rejected while for sex, age and school category were accepted. This indicated negligible difference existed between level of work passion of SILs and age sex and school category. The findings of the study support Sourceright (2016) and Twenge (2010) that socio-demographic variables like length of service and experience have significant impacts on the work passion of a member of an organization. 
Table 12. Difference on level of work passion of SILs according to the selected profiles

\begin{tabular}{lccl}
\hline \multicolumn{1}{c}{ Component } & t or f-value & $\begin{array}{c}\text { Significant } \\
\text { Value }\end{array}$ & Probability \\
\hline 1. Sex & 0.091 & 0.927 & Not Significant \\
2. Age & 0.557 & 0.574 & Not Significant \\
3. School category & 1.475 & 0.231 & Not Significant \\
4. Educational qualification & 9.802 & 0.000 & Significant \\
5. Length of service & 4.271 & 0.015 & Significant \\
\hline
\end{tabular}

Relationship on management challenges and work passion of school instructional leaders under the new framework and plan of action

Revealed in Table 7 is the significant relationship on the extent of management challenges and the level of work passion of the respondents. Results showed there is a significant relationship on the extent of the respondents ${ }^{\text {ee }}$ management challenges and their passion for work. The Pearson r-ratio of 0.732 has a p-value of 0.000 which is less than 0.05 alpha level of significance. Therefore, the null hypothesis which states that there is no significant relationship on extent of management challenges and level of work passion of SILs is rejected. The extent of management challenges and level of work passion of SILs are significantly related. It showed SILs with a high extent of management challenges also have a high level of work passion. Similarly, SILs with low extent of management challenges have a low level of work passion.

Table 13. Relationship between the respondents' management challenges and work passion

\begin{tabular}{lccc}
\hline & Pearson r-ratio & p-value & Probability \\
\hline $\begin{array}{l}\text { Extent of management challenges } \\
\text { Level of work passion }\end{array}$ & 0.732 & 0.000 & Significant \\
\hline
\end{tabular}

Proposed learning and development plan under the new framework

An output entitled "SILs: Igniting Work Passion in Challenging Times" was made based on the results of the study with the main aim of helping the SILs in managing challenges and in strengthening their work passion under the new framework and plan of action. The proposed Learning and Development Plan was prepared by the researcher with the intent to submit such to the respective Human Resource Development Sections of the Schools Division Offices of Roxas City and Capiz. The researcher hopes to collaborate with these two offices in implementing the output of the study.

\section{Conclusions}

Based on the findings of the study, the following conclusions are drawn:

1. The management capability of instructional leaders were highly challenged by the delivery of the new learning modality policies, encouraging teachers with less prior knowledge and learning on how to develop and produce supplementary learning resources and materials suited to the learners' competencies and establish an inventory system of quality-assured modules. Likewise, the inadequacy of resources, commodities and infrastructure to assure the safety of teaching personnel and support staff as well as the precautionary and mitigating measures concerning Covid-19 and the conduct of technology enhancement programs for teachers through webinars/seminars, trainings, and workshops added to the burden of school leaders.

2. The level of work passion of school leaders was remarkably high manifested by being passionate towards work, stayed in the profession despite of the challenges and health risks, willingness to work together with others and maintaining positive stance, build and encourage cooperative relationships with teachers and the community, establish environment and culture that enhance collaboration, cooperation and encouragement among the members and provide opportunities to teachers to learn, grow professionally, and develop skills necessary for the current learning modality.

3. The extent of management challenges of SILs varies only when their educational qualification and length of service are considered, other factors failed to establish connection.

4. The level of work passion of SILs exhibited variation when educational qualification and length of service are considered signifying dependency of work passion to the variables.

5. Management challenges and work passion of SILs interrelated with each other. The higher the extent of management challenges, the higher also is the level of work passion and vice-versa. 


\section{Implications}

Digital world demands management especially in school to be computer savvy. Schools have a bulk of paper work to make and accomplish and if an administrator has limited knowledge in computers, the difficulty of accomplishing papers and others will be doubled. A paperless transaction needs a personnel who is updated on technologies. If a school cannot meet that because of other reasons, funds, accounting problems and liquidations will take time. Therefore, the priority would be training schools to enhance the computer literacy of officials. With this pandemic, the passion of teachers for teaching is commendable. Aside from the bulk of work they have at present it is thrice heavier than before. Teachers have platforms to make, conduct classes even beyond schedule and have to repeat the lesson twice or thrice notwithstanding they are also exposed to health risks. The giving of rewards and recognition and providing career growth and development to all would be suitable more so in far flung areas.

In relation to management challenges faced by SILs, the Schools may examine various programs, projects and activities that would promote or enhance educational opportunities like master's or a doctorate degree through training grants or scholarship programs. This can be based on their needs and capabilities.

\section{References}

Bandura, A. (1994). Self-efficacy. In V. S. Ramachaudran (Ed.), Encyclopedia of human behavior (Vol. 4, pp. 71-81). New York:

Basilaia, G. \& Kvavadze, D. (2020). Transition to Online Education in Schools during a SARS-CoV-2

Coronavirus (COVID-19) Pandemic in Georgia. Pedagogical Research, v5 n4. EJ1263561_ISSN: EISSN2468-492

Briones, 2020). Education ministers unite to ensure learning continuity amid COVID-19. Press Release. 2020.

Buenviaje 2016. Quest Journals Journal of Research in Business and Management Volume $4 \sim$ Issue 5(2016) pp: 16-21 ISSN. : 2347-3002

Cabaro, G. A. and Canoy, S. S. (2014). Secure connected domination in a graph, International Journal of

Mathematical Analysis 8 (42) (2014) 2065-2074

Escobedo, Revsee A. OIC-Undersecretary, Department of Education, DepEd Complex, Meralco. DepEd. Dept. Order.

Farah, A. I. (2013). School Management: Characteristics of Effective Principal. Global Journal of Human Social Science, Volume 13 Issue 13 Version 1.0: Double Blind Peer Reviewed International Research Journal: Global Journals Inc. (USA): Online ISSN: 2249-460x \& Print ISSN: 0975-587X.

Fisher, C. D. (2010). Happiness at Work. International Journal of Management Reviews, 12, 384-412.

Johnson, J. (2010). The principal's priority 1. Educational Leadership, volume 66, issue1, pp72-76.

Killon, J. (2015). Personalization. Principal Leadership (High School Ed.), volume 6, issue 3, pp54-55.

Lavigne, G. L., Forest, J., Fernet C. and Crevier-Braud, L. (2014). Passion at Work and Workers' Evaluations of Job demands and Resources: A longitudinal study. Journal of Applied Psychology, Vol: 44 pp. 255-265.

Leithwood, K., Harris, A. \& Hopkins, D. (2019): Seven strong claims about successful school leadership revisited, School Leadership \& Management, DOI:10.1080/13632434.2019.1596077

Mao, H.Y., \& Hsieh, A.T. (2012). Role ambiguity, employee gender, and workplace friendship. Psychological Reports, 110(3), 719-730. https://doi.org/10.2466/01.07.21.PR0.110.3.719-730

Mulford, B. (2008). The Leadership Challenge: Improving Learning in Schools. Victoria, Australia.

Mushaandja, J., Haihambo, C., Vergnani, T. \& Frank, E (2013). Major challenges facing teacher counselors inschools in Namibia. Educational Journal, 2(3), 77-83

Northouse, P. G. (2015). Introduction to leadership: concepts and practice. Third edition. Thousand Oaks, CA: SAGE Publications.

Revsee Escobedo (2019). Northern Mindanaohttp://27.110.168.75 > rox > Advisory > 2019 > R...PDF

Steinberg, M., Allensworth, E., \& Johnson, D. (2011). Student and teacher safety in Chicago public schools: The roles of community context and school social orga-nization. Chicago, IL: Consortium on Chicago School Research.Stigler, J. W., \& Hiebert, J. (1999). The teaching gap: Best ideas

Touchton, D. J., Rodriguez, M. A., Ivory, G., and Acker-Hocevar, Michele (2018). Quandaries of School Leadership: Voices from Principals in the Field. Cham, Switzerland.

Twenge (2010 Twenge, J. M. (2010). A review of the empirical evidence on generational differences in work attitudes. Journal of Business and Psychology, 25(2), 201-210. https://doi.org/10.1007/s10869-010-9165-6 